\title{
Sea bass fish Morone sp. (Teleostei) from the north Bohemian Palaeogene (Tertiary, Czech Republic)
}

\author{
TOMÁŠ PŘIKRYL
}

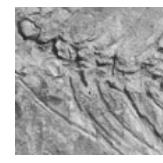

\begin{abstract}
The taxonomic position of sea bass fishes of the family Moronidae from Upper Eocene (Palaeogene) diatomite deposits of Kučlín near Bílina, Czech Republic, is discussed. Although the fossil skeletons are incomplete, Morone sp. is characterised by skull elements, fin formula, caudal skeleton and specific ctenoid scales. The morphology of certain skull elements typifies the family. Data on moronid fishes from the northern Bohemian Palaeogene is reviewed. $\bullet$ Key words: fish, Teleostei, Perciformes, Moronidae, Czech Republic, Eocene, Priabonian.
\end{abstract}

PřIKRYL, T. 2008. Sea bass fish Morone sp. (Teleostei) from the north Bohemian Paleogene (Tertiary, Czech Republic). Bulletin of Geosciences 83(1), 117-122 (4 figures, 2 tables). Czech Geological Survey, Prague. ISSN 1214-1119. Manuscript received May 2, 2007; accepted in revised form September 3, 2007; issued January 31, 2008.

Tomáš Přikryl, Charles University, Faculty of Science, Institute of Geology and Palaeontology, Albertov 6, 12843 Praha 2, Czech Republic; Prikryl.T@seznam.cz.

Fossil fishes are relatively common in the freshwater Palaeogene diatomite deposits of the Kučlín locality near Bílina (e.g., Fejfar \& Kvaček 1993, Obrhelová 1987). The fish fauna from the Kučlín diatomites consists of Cyclurus macrocephalus Reuss, 1844, Bilinia uraschista (Reuss, 1844), Thaumaturus furcatus Reuss, 1844 and Morone sp. The systematics of these fishes has been discussed by many authors (e.g., Grande \& Bemis 1998; Micklich 1990; Micklich \& Böhme 1997; Obrhelová 1971, 1975, 1987). A taxonomic list of the fauna is summarized by Fejfar \& Kvaček (1993). Information about the flora is reported in Bellon et al. (1998), Kvaček (2002) and Kvaček \& Walter (2003).

The first skeletal evidence of the family Moronidae was found in Grube Messel, dated as Eocene, Lutetian Stage in Patterson (1993). Moronid skeletons and otoliths are also quite common in the Oligocene and Miocene deposits of central and western Europe; for a summary see Böhme \& $\operatorname{Ilg}(2003)$.

Fishes of the family Moronidae (sea basses) are fast-moving marine fishes with anadromic migration habits, migrating into freshwater to spawn (Nelson 1994). Micklich \& Böhme (1997) suggested a connection between the Kučlín Lake and the Eocene "North Sea" (see Fig. 15 in Micklich \& Böhme, 1997). The presence of moronid fishes at the Kučlín locality was determined by Micklich (1990) and Micklich \& Böhme (1997) based on the fragmentary material of the head, part of the body and ctenoid scales (National Museum Prague: Kuč30a, Kuč30b, Kuč80; Institut für Geophysik und Geologie der
Universität Leipzig: MB Kuč.13 - today in the National Museum Prague as Pc2853; Naturhistorischem Museums Wien: 1864/XL/1961). New specimens will be described here with a review of the Bohemian material.

\section{Geological setting}

The studied material was collected from laminated diatomaceous deposits exposed at the Trupelnik Hill (355.8 m), northeast of Kučlín village. A description of the outcrop was given by Mrázek \& Procházka (1953), summary was given by Kvaček (2002).

Tertiary sediments are a relict of the old Kučlín lake sedimentary area and lie upon Upper Cretaceous sediments. These volcanogenic deposits of the České středohoři Mountains were accumulated during the Late Eocene to Early Oligocene (Fejfar \& Kvaček 1993). The lowermost part of the Palaeogene sediments is formed by pyroclastics continuing into marlstone (thickness about $15 \mathrm{~m}$ ). The rest of the deposits are composed of various kinds of diatomite with volcanogenic admixture (Mrázek \& Procházka 1953). This section belongs to the Ústí Formation, accumulated during the upper Priabonian this is based on fossil flora evidence (Kvaček 2002). The top of the sedimentary body is covered by a basaltic sheet. A radiometric date obtained from the tephrite indicates $38.3 \pm 0.9 \mathrm{My}$ (Bellon et al. 1998). The diatomites accumulated in a high-productivity environment (Fejfar \& Kvaček 1993). 


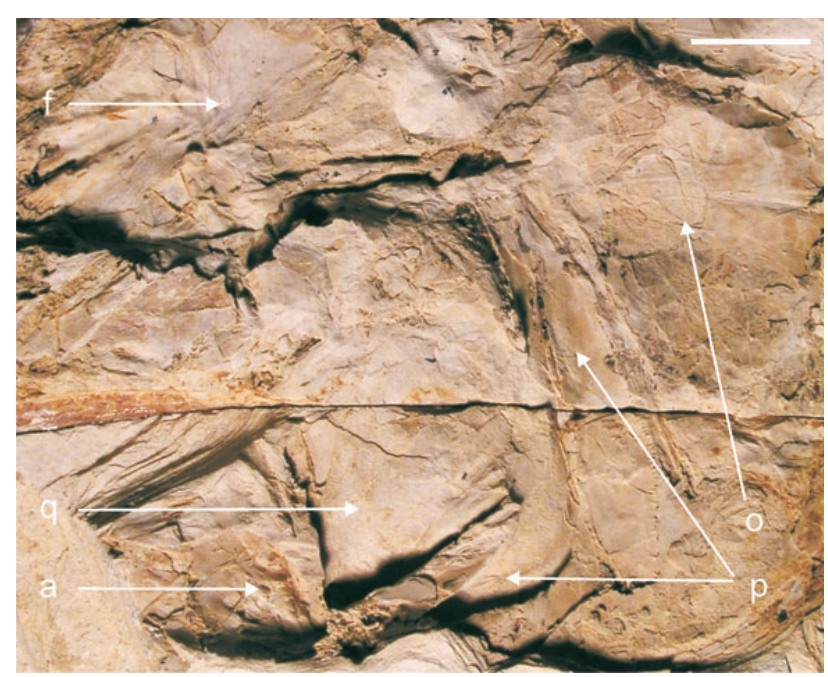

Figure 1. Morone sp., Pc2854: part of a head, left side. Eocene, Kučlín. Scale bar represents $10 \mathrm{~mm}$.

\section{Material and methods}

The following fossil fish material from the Kučlín locality housed at the Department of Palaeontology, National Museum, Prague, has been evaluated in this study: Kuč30a - part of a head; Kuč30b - part of a head; Pc2850 - an almost complete fish without caudal fin; Pc2854 - anterior part of body with head; Pc2853 = IGGL MB Kuč.13 in Micklich \& Böhme (1997) - posterior part of body; Kuč80 - scale. Z. Dvořák's collection, Bílina Mine: DB - caudal part of body with caudal fin. Comparative recent material: Perciformes; Percidae; Perca fluviatilis Linnaeus, 1758; Europe. Perciformes; Moronidae; Morone labrax (Linnaeus, 1758); Atlantic.

Anatomical abbreviations: A - anal fin; a - articulare; a. c. - articular condyle; a. p. - processus ascendens; c. m. - corpus maxillaries; c. pm. - corpus premaxillaris; c. q. - corpus quadrati; d - dentary; d. p. - processus dorsalis; D1 - first dorsal fin; D2 - second dorsal fin; f - frontal; f. 1. p. - frontal lateral plate; f. s. - fossa sympletica; 1. d. - lamina dorsalis; 1. p. - lateral plate; 1. v. - lamina ventralis; la - lacrimale; $\mathrm{m}$ - maxilla; $\mathrm{o}$-operculum; $\mathrm{p}$ - preoperculum; p. p. - processus posterior; p. pm. - processus postmaxillaris; $\mathrm{pa}$ - palatinum; $\mathrm{pm}$ - premaxilla; $\mathrm{q}$-quadrate; r. h. - ramus horizontalis; r. v. - ramus verticalis; s. p. - sulcus praeoperculi; SL - estimated standard length.

\section{Systematic palaeontology}

Family Moronidae sensu Johnson, 1984

\section{Genus Morone Mitchill, 1814}

Type species. - Morone labrax (Linnaeus, 1758), S Europe, Recent.

\section{Morone sp.}

Figures 1, 2A-C, 3A-D

1851 Perca lepidota Agassiz, 1844. - von Meyer, pp. 56, 57, pl. 12, fig. 1.

1971 Bilinia uraschista (Reuss, 1844). - Obrhelová, pl. 4, fig. 6.

1990 Percoidei indet. [non Bilinia Obhelová, 1971]. - Micklich, p. 201, fig. 1.

1990 Bilinia sp. Obhelová, 1971. - Micklich, p. 202, fig. 2.

1997 Morone sp. - Micklich \& Böhme, p. 121, text-figs $4,5$.

Description. - The studied specimens have incomplete bodies, which are fusiform and shallow in lateral view. The estimated standard length rate on the basis of Pc2853 is about $30 \mathrm{~cm}$ (Micklich \& Böhme 1997); $30 \mathrm{~cm}$ based on Pc2850; and $35 \mathrm{~cm}$ based on Pc2854. The maximum body depth is in front of the first dorsal fin. There are two poorly preserved dorsal fins on specimen Pc2850. Two spines and less than seven rays are preserved in the ventral fin. The anal fin on Pc2850 supports three spines. Measurements of the studied specimens and percentages of the estimated standard length are given in Table 1. Micklich (1990) determined certain cranial elements in Kuč30a and Kuč30b: frontal (fr), lacrimale (la), palatinum (pa), maxilla (mx), articulare or more precisely angulo-articulare (an) and preoperculum (po).

Using the new specimens it was possible to distinguish the following skull elements (Figs 1, 2A, B): frontal (f), lacrimale (la), palatinum (pa), premaxilla (pm), maxilla (m), dentary (d), articulare (a), quadrate (q), preoperculum (p) and operculum (o).

Frontal (based on Pc2854, Kuč30a): a wide triangular bone with anteriad elongation and radial ornamentation; a wide frontal lateral plate (f. 1. p.) with a clear convexly curved lateral margin; the sensory canal terminates in two anterior spurs.

Premaxilla (Fig. 3B; specimen Kuč30b; preservation without teeth): a wide corpus premaxillaris (c. pm.); a processus postmaxillaris (p. pm.) with a wide base.

Maxilla (Fig. 3D; specimens Kuč30a, Kuč30b): large ventral portion of corpus maxillaris (c. m.); articular head with narrow lateral plate (1. p.) and long processus dorsalis (d. p.).

Dentary (Kuč30b; badly preserved): a few rows of small teeth on the teeth patch.

Articulare (Pc2854, Kuč30a; badly preserved): a triangular processus coronoideus without curvature.

Quadrate (Fig. 3C; specimens Pc2850, Pc2854, Kuč30a): a wide corpus quadrati (c. q.); a large articular condyle (a. c.); the processus posterior (p. p.) is pointed and long; a distinct fossa sympletica (f. s.); the sulcus praeoperculi (s. p.) does not extend the total length of the processus posterior (p. p.).

Preopercle (Fig. 3A; specimens Pc2850, Pc2854, 

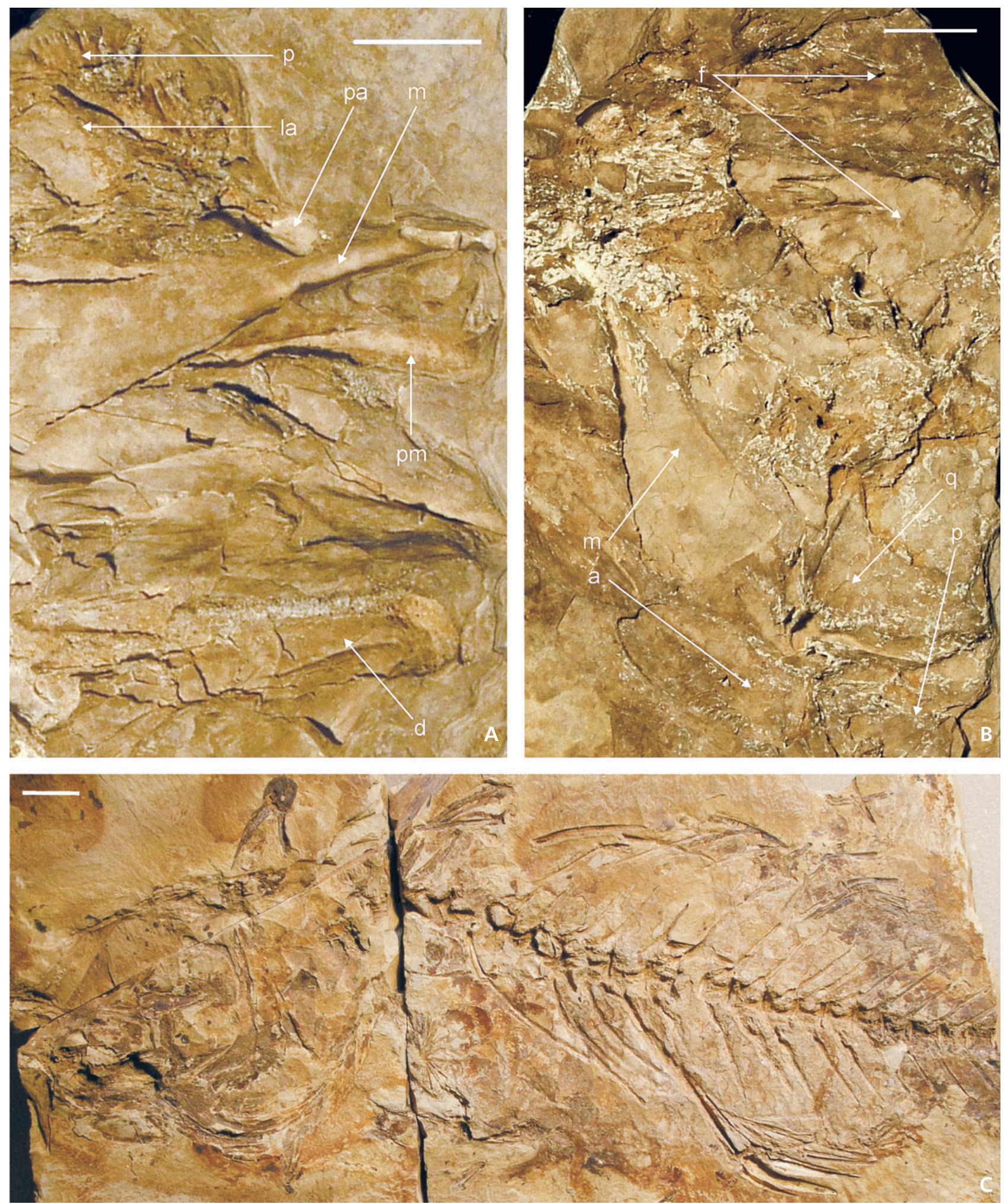

Figure 2. Morone sp. • A - Kuč30b, part of the head. • B - Kuč30a, part of the head. • C-Museum no Pc2850, an almost complete fish without caudal fin; Left side. Scale bar represents $10 \mathrm{~mm}$. 

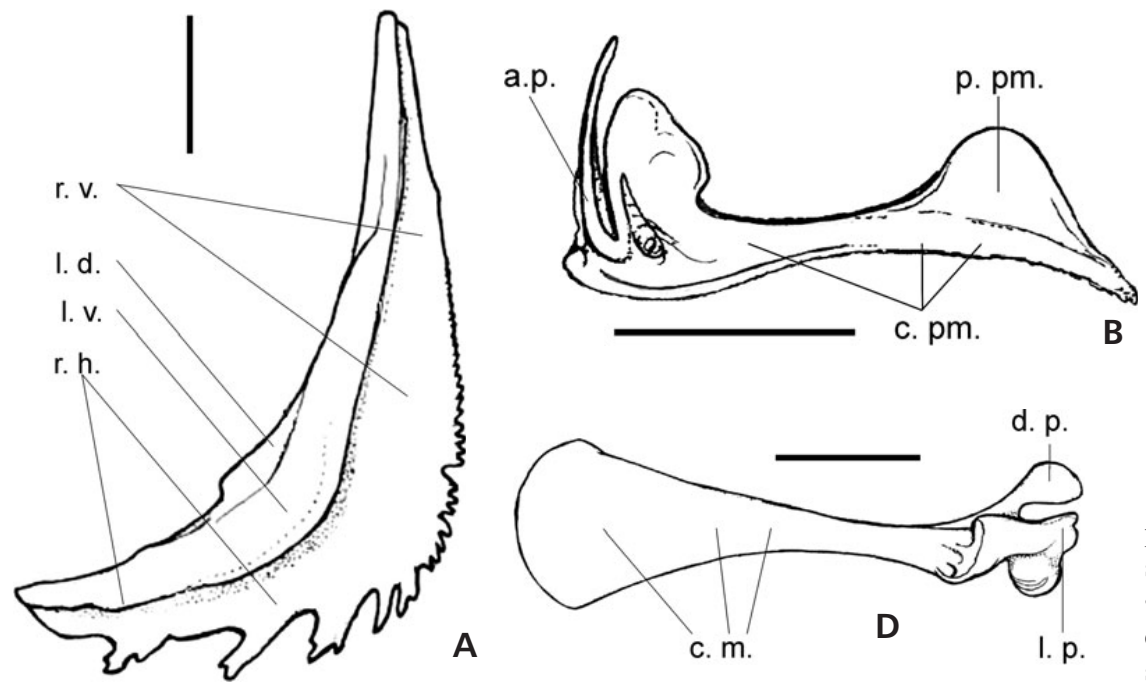

d. p.

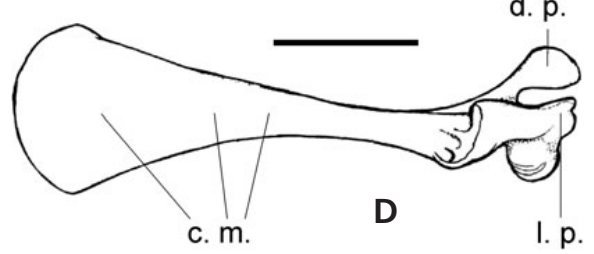

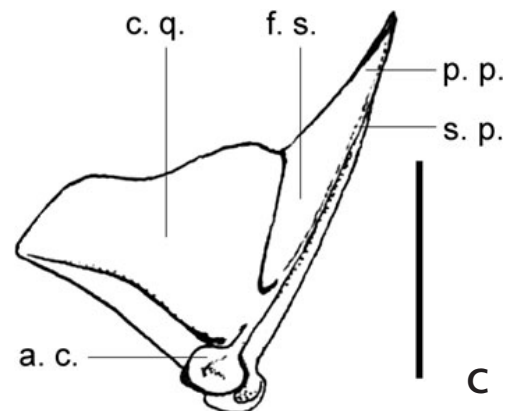

Figure 3. Morone sp. $\bullet$ A - reconstruction of the preopercle, left side, lateral view. $-\mathrm{B}$ - reconstruction of the premaxilla, left side, lateral view. - $\mathrm{C}$ - reconstruction of the quadrate, left side, lateral view. $\bullet$ D - reconstruction of the maxilla, left side, lateral view. Scale bar represents $10 \mathrm{~mm}$.
Kuč30a, Kuč30b): sickle-shaped form; a long pointed ramus verticalis (r. v.); the ramus horizontalis (r. h.) is short but the anteriormost part is not preserved; the ratio of lengths of the ramus verticalis and ramus horizonatlis is 3 to 2 ; a narrow and short lamina dorsalis (1. d.); a large lamina ventralis (1. v.); a serrate posterior margin to the preopercle; the ventral margin of the ramus horizontalis has probably five spiny projections, some of which are bifurcate.

Opercle (Pc2850, Pc2854; badly preserved): a triangular bone with two posterior spiny-projections.

The lacrimale and the palatinum were described by Micklich (1990).

The vertebral column is not completely preserved but probably, there are about 25 vertebrae. This estimation is based on seven centra that are preserved on Pc2853, which are located behind the posterior margin of the second dorsal fin, and on 17-18 centra preserved in front of the posterior margin of the second dorsal fin on Pc2850.

Key features such as fin spine and ray counts are not clearly discernible. The studied specimens have unknown spine counts and no rays on the first dorsal fin and unknown spine and ray counts for the second dorsal fin. The anal fin is composed of three rigid spines and of an unknown number of soft rays. The ventral fin has less than seven soft rays preceded by two rigid spines. Other fin rays are uncountable in the studied specimens.

The caudal skeleton was described by Micklich \& Böhme (1997). The medium ctenoid scales are a subquadrangular shape. The nucleus (if it is present) is oval and its axis is perpendicular to the anteroposterior axis of the scale. The anterior margin of the scale is straight and the posterior rounded. The posterior (ctenoid) field is highly spread out (about $170^{\circ}$ ). Typically, ctenii are not needle-like but short and broad. Detailed scale morphology and comparison with recent representatives of family Moronidae were discussed by Micklich (1990) and Micklich \& Böhme (1997). Annuli are not obvious on the scales.

\section{Discussion}

Fossil specimens were compared with recent representatives of the families Moronidae [Morone labrax (Linnaeus, 1758)] and Percidae [Perca fluviatilis Linnaeus, 1758].

Comparing Morone labrax and Perca fluviatilis skull morphology and the studied fossil specimens:

The frontal has radial ornamention and a wide f. 1. p. (with a clear convexly curved lateral margin) in the fossils and in M. labrax and a narrow f. 1 . p. (with a concave curved lateral margin) in P. fluviatilis. The sensory canal terminates in two anterior projections in the fossils and M. labrax and in only one anterior projection (it clings to the midline of skull roof) in P. fluviatilis. The ratio of the frontal length to width is 3.8 to 1.6 in the fossil Kuč30a, 3.7 to 1.5 in M. labrax and 3 to 1 in P. fluviatilis. The M. labrax premaxilla (Fig. 4D) has a large corpus premaxillaris (c. pm.) and a wide processus postmaxillaris (p. pm.); P. fluviatilis has a triangular processus ascendens (a. p.) at the premaxilla (Fig. 4C). In M. labrax and the fossils the maxilla (Fig. 4A) has a straight lateral plate and a long processus dorsalis (d. p.) compared to $P$. fluviatilis where the maxilla has a portly articular head and a short spherical processus dorsalis (Fig. 4B). The ratio of corpus maxillaris width and length is 1.5 to 3.5 in the studied fossils, 0.9 to 2.7 in M. labrax, and 0.7 to 2.4 in $P$. fluviatilis. The quadrate (Fig. 4G) has a long processus posterior (p. p.) in M. labrax and a short one in P. fluviatilis. The ratio of the lengths of the preopercular ramus verticalis and the ramus horizontalis equals 3 to 2 in M. labrax and the fossils rather than 2 to 1 in $P$. fluviatilis. The lamina ventralis (1. v.) is very well developed in the studied specimens and M. labrax (Fig. 4E) and badly developed in P. fluviatilis (Fig. 4F). The operculum has two spines in the studied fossils and M. labrax but only one spine in P. fluviatilis. A comparison of fins and vertebral number of the studied fossil Morone sp. with the recent representatives Morone labrax and Perca fluviatilis is shown in Table 2. 


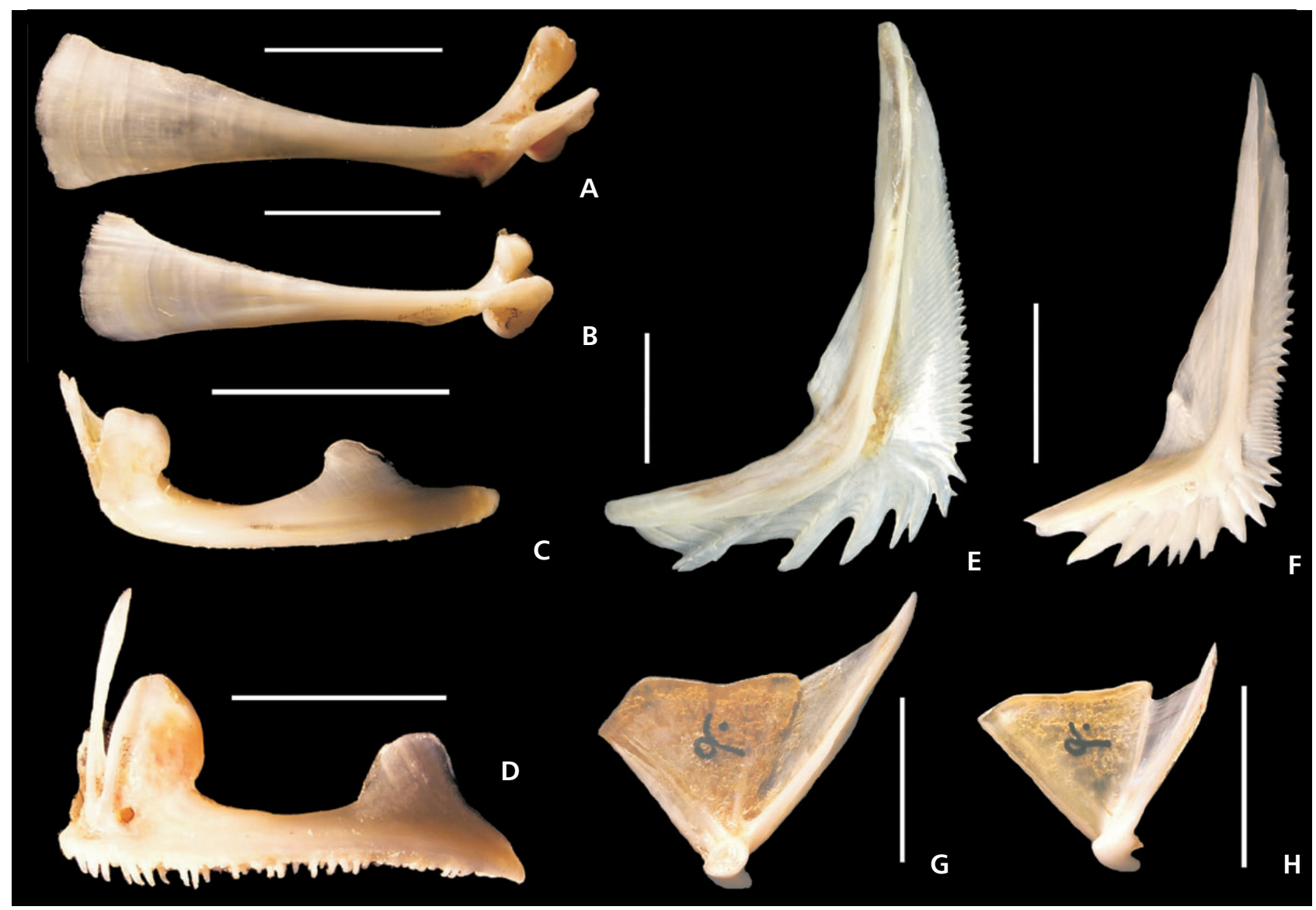

Figure 4. Morone labrax (Linnaeus, 1758). $\bullet A$ - maxilla, left side, lateral view. $\bullet \mathrm{D}$ - premaxilla, left side, lateral view. $\bullet \mathrm{E}$ - preopercle, left side, lateral view. $\bullet \mathrm{G}$ - quadrate, left side, lateral view. Perca fluviatilis Linnaeus, $1758 \cdot \bullet \mathrm{B}-$ maxilla, left side, lateral view. $\bullet \mathrm{C}-$ premaxilla, left side, lateral view. $\bullet \mathrm{F}$ - preopercle, left side, lateral view. $\bullet \mathrm{H}$ - quadrate, left side, lateral view. Scale bar represents $10 \mathrm{~mm}$.

Members of the extant Moronidae have certain diagnostic characters (e.g., Nelson 1994): two dorsal fins, D1VIII-X, D2 I, 10-13; A III, 9-12; an operculum with two spines; a lateral line extends almost to posterior margin of the caudal fin; there is an auxillary row of lateral line scales on the caudal fin above and below the main row; seven branchiostegal rays; and 25 vertebrae. Characteristic recent moronid scales have: broad pentagonal ctenii with straight proximal ends and a straight median shaft (McCully 1961); truncated ctenial bases that are quadrangular and regular both in shape and arrangement; ctenii that are never needle-like (Coburn \& Gaglione 1992).

Features in the fossils, such as the frontal sensory canal that terminates in two projections, the quadrate with a long processus posterior, the ratio of the lengths of the preopercular ramus verticalis and ramus horizonatlis being 3 to 2, the large lamina ventralis and the presence of bifurcate spines, an operculum with two spines, an anal fin with three rigid fin spines, and 25 vertebrae all suggest a possible affinity to the extant Morone. The scale morphology of the family Moronidae is also the same as the studied fossils (see also Micklich 1990 and Micklich \& Böhme 1997).
Table 1. Measurements of fossils (in mm).

\begin{tabular}{|c|c|c|c|c|c|c|c|c|c|}
\hline & \multicolumn{2}{|c|}{$\operatorname{Pc} 2850$} & \multicolumn{2}{|c|}{ Pc2854 } & \multicolumn{2}{|c|}{ Pc2853 } & \multirow[t]{2}{*}{$\begin{array}{l}\text { Kuč } \\
30 b\end{array}$} & \multirow[t]{2}{*}{$\begin{array}{l}\text { Kuč } \\
30 \mathrm{a}\end{array}$} & \multirow[t]{2}{*}{$\mathrm{DB}$} \\
\hline & & $\begin{array}{c}\% \text { of } \\
\text { SL }\end{array}$ & & $\begin{array}{c}\% \text { of } \\
\text { SL }\end{array}$ & & $\begin{array}{c}\% \text { of } \\
\text { SL }\end{array}$ & & & \\
\hline estimated standard length & 300 & - & 350 & - & 300 & - & $?$ & $?$ & $?$ \\
\hline anal fin length & 39 & 13 & - & - & - & - & - & - & - \\
\hline body depth & 90 & 30 & 101 & 28.9 & - & - & - & - & - \\
\hline caudal fin length & - & - & - & - & - & - & - & - & 37 \\
\hline caudal penducle depth & - & - & - & - & 44 & 14.7 & - & - & - \\
\hline eye diameter & 22 & 7.3 & - & - & - & - & - & - & - \\
\hline head depth & 77 & 25.7 & 84 & 24 & - & - & - & - & - \\
\hline head length & 97 & 32.3 & 94 & 26.9 & - & - & - & - & - \\
\hline maxilla depth & - & - & - & - & - & - & 13 & 16 & - \\
\hline maxilla length & - & - & - & - & - & - & 44 & - & - \\
\hline preanal length & 195 & 65 & - & - & - & - & - & - & - \\
\hline predorsal length & 151 & 50.3 & - & - & - & - & - & - & - \\
\hline preorbital length & 35 & 11.7 & - & - & - & - & - & - & - \\
\hline postorbital length & 40 & 13.3 & - & - & - & - & - & - & - \\
\hline preventral length & 120 & 40 & - & - & - & - & - & - & - \\
\hline
\end{tabular}


Table 2. Comparison of fin and number of vertebrae of fossil Morone with the recent representatives Morone labrax and Perca fluviatilis (for data see Nelson 1994, Pospíšil 1998 and Froese \& Pauly 2007).

\begin{tabular}{|c|c|c|c|c|c|c|}
\hline & \multicolumn{2}{|c|}{ fossil Morone sp. } & \multicolumn{4}{|c|}{ Morone labrax Perca fluviatilis } \\
\hline & spines & rays & spines & rays & spines & rays \\
\hline first dorsal fin & unknown & 0 & VIII-X & 0 & XII-XVI & 0 \\
\hline second dorsal fin & unknown & unknown & I & $10-13$ & I-III & $12-16$ \\
\hline pectoral fin & unknown & unknown & 0 & $15-16$ & 0 & 14 \\
\hline ventral fin & II & $<7$ & I-II & $5-6$ & I & 15 \\
\hline anal fin & III & unknown & III & $9-12$ & II & $7-10$ \\
\hline caudal fin & 0 & unknown & 0 & 17 & 0 & 17 \\
\hline vertebrae & 25 & & 25 & & $39-4$ & \\
\hline
\end{tabular}

The fossils cannot be referred to either the family Centropomidae (one spine in the ventral fin only), Percichthyidae (the ctenoid scales with simple needle-like ctenii on the posterior field), or Serranidae (the operculum with three spines, the ventral fin with one spine only), according to Nelson (1994).

\section{Conclusions}

This paper presents important information on the entire moronid fishes known from North Bohemian Paleogene. The study is based on comparison of a series of fossils from Kučlín with recent representatives of the families Moronidae [Morone labrax (Linnaeus, 1758)] and Percidae [Perca fluviatilis Linnaeus, 1758]. The presence of the genus Morone is confirmed based on well preserved specimens. Detailed morphology of skull elements (frontal, premaxilla, maxilla, quadrate, preoperculum and operculum), estimated number of vertebrae, fin formula, caudal skeleton (Micklich \& Böhme 1997) and scales (Micklich 1990 and Micklich \& Böhme 1997), shows direct affinity to the family Moronidae, genus Morone.

There is no significant similarity between the recent genus Perca and the studied specimens. Consequently, the assignment to the species "Perca" lepidota is not acceptable. The proposed determination for the studied fossils is Morone sp. These conclusions confirm the study of Micklich \& Böhme (1997).

From the palaeoecological point of the view, the ctenoid scales of Morone sp. without marked annuli suggest that a uniform climate without grand temperature fluctuations existed at the time of the diatomite deposition.

\section{Acknowledgements}

The author acknowledges research support from the Grant Agency of the Czech Republic Grant No. 205/05/0204.

\section{References}

AGASSIZ, L. 1844. Recherches sur les poissons fossiles. Tome 5.160 pp. Petitpierre, Neuchâtel.

Bellon, H., BƯŽEK, Č., GAUdAnt, J., KVAČEK, Z. \& WAlther, H. 1998. The České středohoří magmatic complex in Northern Bohemia ${ }^{40} \mathrm{~K}^{-40} \mathrm{Ar}$ ages for volcanism and biostratigraphy of the Cenozoic freshwater formations. Newsletters on Stratigraphy 36(2/3), 77-103.

BÖHme, M. \& ILG, A. 2003. Fossil Fishes, Amphibians, Reptiles fosFARbase. www.wahre-staerke.com.

COBURN, M.M. \& GAGLIONE, J.I. 1992. A comparative study of percid scales (Teleostei: Perciformes). Copeia 1992(4), 986-1001. DOI $10.2307 / 1446628$

FEJFAR, O. \& KVAČEK, Z. 1993. Exkursionsführer zur Exkursion “Tertiary basins in Northwest Bohemia”, 35 pp. Univerzita Karlova, Česká geologická společnost, Prague.

Froese, R. \& PAUly, D. 2007. FishBase. www.fishbase.org.

GRANDE, L. \& BEMIS, W.E. 1998. A comprehensive phylogenetic study of amiid fishes (Amiidae) based on comparative skeletal anatomy. Journal of Vertebrate Paleontology 18 (Supplement to No. 1), 1-690.

JoHnson, G.D. 1984. Percoidei: development and relationships, 464-498. In Moser, H.G., RichARDS, W.J., COHEN, D.M., FAHAY, M.P., KENDALL, A.W. JR. \& RICHARDSON, S.L. (eds) Ontogeny and systematics of fishes. American Society of Ichthyologists and Herpetologists, Special Publication. Lawrence, Kansas.

KVAČEK, Z. 2002. Late Eocene landscape, ecosystems and climate in northern Bohemia with particular reference to the locality of Kučlín near Bílina. Bulletin of Czech Geological Survey 77(3), 217-236.

KVAČEK, Z. \& WALTER, H. 2003. Reconstruction of vegetation and landscape development during volcanic activity in the České Středohoří Mountains. Geolines 16, 60-64.

LINNAEUS, C. 1758. Systema naturae per regna tria naturae, secundum classes, ordines, genera, species, cum characteribus, differentiis, synonymis, locis. $10^{\text {th }}$ edition. 824 pp. Holmiae, Stockholm.

MCCULLY, H.H. 1961. The comparative anatomy of the scales of the serranid fishes. 208 pp. PhD thesis, Stanford University, California.

MEYER, H. von 1851. Beschreibung der fossilen Decapoden, Fische, Batrachier und Säugetiere aus den tertiären Süßwassergebilden des nördlichen Böhmens. Palaeontographica 2, 43-73.

MiCKLICH, N. 1990. Ein neuer Percoide (Pisces, Perciformes) aus den tertiären Süßwasser-Diatomiten von Kučlín in Böhmen. Senckenbergiana lethaea 70(1/3), 199-208.

MicKLICH, N. \& BÖHME, M. 1997. Wolfsbarsch-Funde (Perciformes, Moronidae) aus den obereozänen Süßwasserdiatomiten von Kučlín in Böhmen nebst kritischer Anmerkungen zur taxonomischen Stellung von "Perca" lepidota aus den Süßwasser-Kalken von Öhningen (Baden). Paläontologische Zeitschrift 71(1/2), 117-128.

MitCHILL, S.L. 1814. Report in part of Samuel L. Mitchill, M.D., on the fishes of New York. 28 pp. New York.

MRÁZEK, A. \& PROCHÁZKA, M. 1953. Zpráva o výzkumu diatomitů v Českém stř̌edohoří. Ložisko diatomitu v Kučlíně. MS Geofond, Praha.

NELSON, J.S. 1994. Fishes of the world. 624 pp. Wiley \& Sons, New York.

OBRHELOVÁ, N. 1971. Über einen Serranid (Pisces) aus dem nordböhmischen Süsswassertertiär. Časopis pro mineralogii a geologii 16(4), 371-387.

OBRHELOVÁ, N. 1975. Osteologischer Bau von Thaumaturus furcatus Reuss, 1844 (Pisces) aus dem nordböhischen Süsswassertertiär (Kučlín bei Bílina). Časopis pro mineralogii a geologii 20(3), 273-290.

OBRHElOVÁ, N. 1987. Paläoichthyologie und Paläökologie des kontinentalen Tertiärs und Quartärs der CSSR. Zeitschrift für geologische Wissenschaften 15(6), 709-731.

PATTERSON, C. 1993. Osteichthyes: Teleostei, 621-656. In BENTON, M.J. (ed.) The Fossil Record 2. Chapman \& Hall, London.

POSPÍŠIL, O. 1998. Svět ryb. 162 pp. Ottovo nakladatelství, Praha.

REUSS, A.E. 1844. Die Kreidegebilde des westlichen Böhmens, ein monographischer Versuch. Nebst Bemerkungen über die Braunkohlenlages jenseits der Elbe und eine Übersicht der fossilen Fischreste Böhmens. 303 pp. C. W. Medau, Prag. 